\title{
Effects of Pruning at Planting on Pecan Trunk Development and Total Shoot Growth
}

\author{
Frederic B. Ouedraogo ${ }^{1}$, B. Wade Brorsen ${ }^{2}$, Jon T. Biermacher ${ }^{3}$, \\ and Charles T. Rohla ${ }^{3}$
}

AdDitional InDEX wORDs. caliper, Carya illinoinensis, limb length, scion, trunk diameter

Summary. Pecan (Carya illinoinensis) trees were pruned using varying intensities at planting to determine the effect of pruning on trunk development and shoot growth. Data on trunk diameter, number and length of shoots, as well as the total shoot growth were recorded annually from a completely randomized design experiment that assigned $0 \%, 50 \%$, and $75 \%$ pruning of above-ground height to single-trunk transplants. The results suggest that pruning intensity has little effect on trunk diameter. The pruned trees had fewer shoots initially and more growth per shoot, leading to a difference of $7 \mathrm{~cm} /$ shoot higher for the $50 \%$ pruning group than the control group and to a difference of $11 \mathrm{~cm} / \mathrm{shoot}$ higher for the $75 \%$ pruning group compared with the control group. The total length of all shoots was not significantly different across treatments. Because previous research has sometimes shown that pruning increases tree survival and this research shows that trees can recover from pruning, there is no need to change the current recommendation of pruning seedlings at planting.

W hen trees are dug from the nursery, a portion of the root system may be lost, therefore the trees can struggle because of lack of stored carbohydrates in the intact root system (Khan et al., 1998). If vigor is increased then, in theory, the trees will start production earlier. Both the root system and the shoot system work jointly to satisfy the resource need of the plant and thus promote growth and stimulate development (Puig et al., 2012; Su et al., 2011). The root system ensures the uptake of water and vital minerals while the shoot system accomplishes reproductive functions and manages photosynthetic activities. When one system faces a resource hardship

Received for publication 7 Nov. 2019. Accepted for publication 6 Feb. 2020

Published online 2 March 2020.

${ }^{1}$ American Veterinary Medical Association, Schaumburg, IL 60173

${ }^{2}$ Department of Agricultural Economics, Oklahoma State University, Stillwater, OK 74078

${ }^{3}$ Noble Research Institute, 2510 Sam Noble Parkway, Ardmore, OK 73401

The research was primarily supported by the Noble Research Institute, LLC. Support was also received from the A.J. and Susan Jacques Chair, as well as the Oklahoma Agricultural Experiment Station and U.S. Department of Agriculture, National Institute of Food and Agriculture Hatch Project number OKL02939.

C.T.R. is the corresponding author. E-mail: ctrohla@ noble.org.

This is an open access article distributed under the CC BY-NC-ND license (https://creativecommons.org/ licenses/by-nc-nd/4.0/).

https://doi.org/10.21273/HORTTECH04535-19 or a disruption of its initial equilibrium, a signal is sent to the other system (Bahrun et al., 2002; Brewer et al., 2013; Kudo et al., 2010), which may react to the new austerity condition. Because roots are typically lost during transplanting, the roots may be unable to support as much stem and shoots as they could before transplanting and so trees are often pruned at planting.

Pecan (Carya illinoinensis) is a multipurpose tree that can be grown at a commercial scale for timber or nuts or as ornamental trees. One unknown is how much pruning at planting is necessary for proper pecan-tree development. Wells (2017) recommends to "prune $1 / 3$ to $1 / 2$ of the top of the tree and remove any branches to compensate for the large percentage of roots lost when the trees are dug." Wood (1996) found reducing trunk height up to $75 \%$ had no effect on tree survival, but did increase growth rate so that there was no difference in the height of pruned and unpruned tress after 3 years; however, Smith and Johnson (1981) found that survival was increased by pruning the tops at planting by $25 \%$ or $50 \%$. Like Wood (1996), Smith and Johnson (1981) also found that pruning increased growth. Meadows and Toliver (1987) found that pecan trees clipped to a 10inch top had recovered to be the same height as unclipped trees after 3 years.

The purpose of this study was to determine if pruning the tops of the single-trunk trees at planting increases vigor of the trees. In the experiment, the tops of bare-root trees were pruned by $50 \%$ or $75 \%$ at planting. The hypotheses considered are 1) pruning newly established pecan trees increases trunk diameter, 2) pruning of newly established single-trunk tree scions will lead to fewer, but longer shoots, and 3 ) pruning will lead to higher total shoot growth. The findings generally support the second hypothesis and the third hypothesis only in year 1 .

\section{Materials and methods}

ExPERIMENTAL DESIGN AND DATA. In Feb. 2007, bare-root pecan trees were planted at the Noble Research Institute's McMillan Research and Demonstration Farm near the community of Madill, OK (lat. $34^{\circ} 2^{\prime} 10$. $4238^{\prime \prime} \mathrm{N}$, long. $96^{\circ} 56^{\prime} 27.0378^{\prime \prime} \mathrm{W}$; elevation $236 \mathrm{~m})$. Trees were sourced from a nursery as a compound tree (3-year-old roots and a 1-year-old scion) with a single trunk, planted in augured $8 \times 18$-inch holes. The single-trunk trees $(\mathrm{N}=2 \mathrm{l})$ had diameters $( \pm$ SD) of $136 \pm 8$ inches. The trees were grafted 'Kanza' pecans on 'Apache' rootstock, were planted at a spacing of $35 \times 35 \mathrm{ft}$ on Bastrop fine sandy loam soil (taxonomic class: fineloamy, mixed, active, thermic Udic Paleustalfs). The soil was well drained, with a depth to the water table of more than 80 inches. Tree roots on all trees were trimmed to 18 inches using cutting shears to fit into the augured hole without twisting roots (McCraw and Smith, 1998; Smith and Johnson, 1981). Trees

\begin{tabular}{llll}
\hline $\begin{array}{l}\text { Units } \\
\text { To convert U.S. to SI, } \\
\text { multiply by }\end{array}$ & U.S. unit & SI unit & $\begin{array}{l}\text { To convert SI to U.S., } \\
\text { multiply by }\end{array}$ \\
\hline 102.7902 & acre-inch(es) & $\mathrm{m}^{3}$ & 0.0097 \\
0.3048 & $\mathrm{ft}$ & $\mathrm{m}$ & 3.2808 \\
2.54 & inch(es) & $\mathrm{cm}$ & 0.3937 \\
25.4 & inch $(\mathrm{es})$ & $\mathrm{mm}$ & 0.0394 \\
1.1209 & lb/acre & $\mathrm{kg} \cdot \mathrm{ha}^{-1}$ & 0.8922 \\
2.3385 & qt/acre & $\mathrm{L} \cdot \mathrm{ha}^{-1}$ & 0.4276
\end{tabular}


were assigned to one of three pruning treatments in a completely randomized design: $0 \%, 50 \%$, and $75 \%$ pruning of above-ground height. After pruning, mean tree height was 136,68 , and 34 inches for the $0 \%, 50 \%$, and $75 \%$ treatments, respectively. The $50 \%$ and $75 \%$ treatments each made use of seven trees with each individual tree serving as a replication. The $0 \%$ control treatment only used six trees because one tree died shortly after planting. A 6 - $\mathrm{ft}$ vegetation-free strip was maintained using glyphosate at a rate of $1.5 \mathrm{qt} /$ acre per year along the row of trees throughout the study. Trees were fertilized with zinc sulfate foliar sprays at a rate of 2 $\mathrm{lb} /$ acre every 2 weeks from budbreak through August. Each tree received $0.5 \mathrm{lb} /$ tree of $46 \mathrm{~N}-0 \mathrm{P}-0 \mathrm{~K}$ (urea) in May of year 1 , and $2 \mathrm{lb} /$ tree $46 \mathrm{~N}-0 \mathrm{P}-$ $0 \mathrm{~K}$ the following years. No diseases were present during the study; however, foliar-feeding insects, including pecan catocala (Catocala sp.), serpentine leafminer (Stigmella junglandifoliella), unicorn caterpillar (Schizura unicornis), pecan budmoth (Gretchena boliana), glassy-winged sharpshooter (Homaladiaca vitripennis), grasshopper (Caelifera), and june beetles (Phyllophaga sp.) were controlled using $0.75 \mathrm{lb} /$ acre chlorpyrifos (Lorsban 4E; Dow AgroSciences, Indianapolis, IN) as needed throughout the study. Trees were irrigated with a solid-set sprinkler system with a riser located next to each tree receiving 0.5 acre-inch irrigation water per week, except when natural rainfall occurred.

One year after planting, and each subsequent year of the trial, the trunk diameter (millimeters) for each tree was measured at $2 \mathrm{ft}$ above the soil line using a digital caliper (Traceable Products, Webster, TX). In addition, the number of shoots were counted and recorded, and the length of shoots measured. Measurements were recorded each year after leaf drop during tree dormancy between December and February each year. The growth of every shoot on the tree was measured each year. Total shoot growth was calculated and recorded for each tree in each year as the summation across all shoots of growth in shoot length.

Statistical analysis. To determine whether pruning alters trunk development, a mixed model with treatment fixed effect (capturing the effect of pruning on trunk diameter) and replicate random effect (capturing the intrinsic differences between experimental subjects) was used. The trunk diameters were compared across the three treatment groups $(0 \%, 50 \%$, and $75 \%$ pruned). The MIXED Procedure in SAS (SAS/STAT version 14.1 in SAS version 9.4; SAS Institute, Cary, NC) was used to estimate the parameters of the model (Littell et al., 1996).

The MIXED procedure was used to analyze both the number and average length of shoots. Both models were assumed to be mixed with tree random effect and the fixed effect of the treatment. For determining the pruning effects on total shoot growth (number of shoots times average length of shoots) a similar mixed model was used.

\section{Results and discussion}

Trunk Diameter. The mean diameter, the annual incremental growth, and the percent change in diameter for each treatment group are presented in Table 1. For measurements taken 1 year after establishment, the descriptive statistics show that the average trunk diameter was higher for the untreated group ( $25 \mathrm{~mm}$ ) followed by the $75 \%$-pruned group $(22 \mathrm{~mm})$, and the $50 \%$-pruned group had the lowest diameter $(20 \mathrm{~mm})$.

During the second year of observation (2009), the annual increment analysis showed that the group with $50 \%$ intensity of pruning had increased on average by $8.6 \mathrm{~mm}$ ( $44 \%$ change in diameter), whereas the control group and the $75 \%$ group both increased $6.8 \mathrm{~mm}$. However, in terms of percentage change in diameter, the control group had the lowest change (30\%).

During the final year of observation (2010), the results indicate that the $50 \%$ pruning group had an increment increase in diameter of $18.8 \mathrm{~mm}$ compared with 2009 . The control had increased by $13.6 \mathrm{~mm}$, whereas the $75 \%$ pruning group had increased by $13.5 \mathrm{~mm}$. Overall, trees in the control group had increased by $20.4 \mathrm{~mm}$, trees that received $50 \%$ pruning had increased by $27.5 \mathrm{~mm}$, and those with the $75 \%$ pruning intensity had increased by $20.2 \mathrm{~mm}$

Table 1. Average trunk diameter and annual growth of young 'Kanza' pecan trees with respect to $0 \%, 50 \%$, and $75 \%$ pruning intensity.

\begin{tabular}{|c|c|c|c|c|c|}
\hline \multirow[b]{2}{*}{ Pruning intensity } & \multicolumn{3}{|c|}{ Trunk diam $(\mathrm{mm})^{\mathrm{z}}$} & \multicolumn{2}{|c|}{$\begin{array}{c}\text { Annual increment } \\
\text { in trunk diam } \\
(\mathrm{mm})\end{array}$} \\
\hline & 2008 & 2009 & 2010 & 2009 & 2010 \\
\hline \multicolumn{6}{|c|}{ Intensity of pruning $0 \%$} \\
\hline $\begin{array}{l}\text { Average } \\
\text { SE }\end{array}$ & $\begin{array}{c}24.63 \mathrm{a}^{\mathrm{y}} \\
(1.75)\end{array}$ & $\begin{array}{l}31.47 \mathrm{a} \\
(1.20)\end{array}$ & $\begin{array}{l}45.04 \mathrm{a} \\
(2.06)\end{array}$ & $\begin{array}{l}6.84 \mathrm{a} \\
(0.86)\end{array}$ & $\begin{array}{l}13.58 \mathrm{a} \\
(2.36)\end{array}$ \\
\hline \multicolumn{6}{|c|}{ Intensity of pruning $50 \%$} \\
\hline $\begin{array}{l}\text { Average } \\
\text { SE }\end{array}$ & $\begin{array}{c}20.11 \mathrm{a} \\
(1.62)\end{array}$ & $\begin{array}{c}28.76 \mathrm{a} \\
(1.11)\end{array}$ & $\begin{array}{c}47.60 \mathrm{a} \\
(1.91)\end{array}$ & $\begin{array}{l}8.64 \mathrm{a} \\
(0.80)\end{array}$ & $\begin{array}{c}18.84 \mathrm{a} \\
(2.18)\end{array}$ \\
\hline \multicolumn{6}{|c|}{ Intensity of pruning $75 \%$} \\
\hline $\begin{array}{l}\text { Average } \\
\text { SE }\end{array}$ & $\begin{array}{c}22.11 \mathrm{a} \\
(1.62)\end{array}$ & $\begin{array}{c}28.87 \mathrm{a} \\
(1.11)\end{array}$ & $\begin{array}{c}42.35 \mathrm{a} \\
(1.91)\end{array}$ & $\begin{array}{l}6.76 \mathrm{a} \\
(0.80)\end{array}$ & $\begin{array}{c}13.48 \mathrm{a} \\
(2.18)\end{array}$ \\
\hline
\end{tabular}

${ }^{\mathrm{z}} 1 \mathrm{~mm}=0.0394$ inch.

${ }^{\mathrm{y}}$ Means in the same column followed by the same letter are not significantly different using Fisher's protected least significant difference at $P<0.05$.

Table 2. Number of shoots and growth per shoot of 'Kanza' pecan trees in relation to year of planting and pruning intensity.

\begin{tabular}{lrrrr}
\hline Level of pruning & $\mathbf{2 0 0 8}$ & $\mathbf{2 0 0 9}$ & $\mathbf{2 0 1 0}$ & All years \\
\hline \multicolumn{5}{c}{ Shoots (no.) } \\
Intensity of pruning 0\% & $12.00 \mathrm{a}^{\mathrm{z}}$ & $19.17 \mathrm{a}$ & $34.50 \mathrm{a}$ & $21.89 \mathrm{a}$ \\
Intensity of pruning 50\% & $7.14 \mathrm{~b}$ & $12.14 \mathrm{~b}$ & $32.57 \mathrm{a}$ & $17.29 \mathrm{a}$ \\
Intensity of pruning 75\% & $4.71 \mathrm{~b}$ & $12.43 \mathrm{~b}$ & $34.14 \mathrm{a}$ & $17.09 \mathrm{a}$ \\
\multicolumn{5}{c}{ Avg shoot growth (cm/shoot) } \\
\hline Intensity of pruning 0\% & $12.09 \mathrm{a}$ & $13.72 \mathrm{a}$ & $19.70 \mathrm{a}$ & $15.17 \mathrm{a}$ \\
Intensity of pruning 50\% & $12.98 \mathrm{a}$ & $26.90 \mathrm{~b}$ & $22.71 \mathrm{ab}$ & $20.86 \mathrm{~b}$ \\
Intensity of pruning 75\% & $23.74 \mathrm{~b}$ & $30.94 \mathrm{~b}$ & $25.60 \mathrm{~b}$ & $26.76 \mathrm{c}$ \\
\hline
\end{tabular}

${ }^{\mathrm{z}}$ Means in the same column followed by the same letter are not significantly different using Fisher's protected least significant difference at $P<0.05$.

${ }^{\mathrm{y}} 1 \mathrm{~cm}=0.3937$ inch. 
Table 3. Total shoot growth of 'Kanza' pecan trees in response to $\mathbf{0 \%}, \mathbf{5 0 \%}$, and $75 \%$ pruning of scion at planting.

\begin{tabular}{|c|c|c|c|c|}
\hline \multirow[b]{2}{*}{ Pruning intensity } & \multicolumn{3}{|c|}{$\begin{array}{l}\text { Annual growth in total shoot length } \\
\qquad(\mathrm{cm})^{\mathrm{z}}\end{array}$} & \multirow[b]{2}{*}{ Total growth } \\
\hline & 2008 & 2009 & 2010 & \\
\hline \multicolumn{5}{|c|}{ Intensity of pruning $0 \%$} \\
\hline $\begin{array}{l}\text { Average } \\
\text { SE }\end{array}$ & $\begin{array}{l}153.43 \mathrm{a}^{\mathrm{y}} \\
(29.97)\end{array}$ & $\begin{array}{c}268.82 \mathrm{a} \\
(37.23)\end{array}$ & $\begin{array}{c}673.00 \mathrm{a} \\
(74.57)\end{array}$ & $\begin{array}{l}1,095.25 \mathrm{a} \\
(71.52)\end{array}$ \\
\hline \multicolumn{5}{|c|}{ Intensity of pruning $50 \%$} \\
\hline $\begin{array}{l}\text { Average } \\
\text { SE }\end{array}$ & $\begin{array}{l}87.50 \mathrm{a} \\
(27.75)\end{array}$ & $\begin{array}{c}323.06 \mathrm{ab} \\
(34.47)\end{array}$ & $\begin{array}{c}738.36 \mathrm{a} \\
(69.04)\end{array}$ & $\begin{array}{l}1,148.91 \mathrm{a} \\
(66.22)\end{array}$ \\
\hline \multicolumn{5}{|c|}{ Intensity of pruning $75 \%$} \\
\hline $\begin{array}{l}\text { Average } \\
\text { SE }\end{array}$ & $\begin{array}{l}113.29 \mathrm{a} \\
(27.75)\end{array}$ & $\begin{array}{c}377.01 \mathrm{~b} \\
(34.47)\end{array}$ & $\begin{array}{c}864.70 \mathrm{a} \\
(69.04)\end{array}$ & $\begin{array}{c}1,355.00 \mathrm{a} \\
(66.22)\end{array}$ \\
\hline
\end{tabular}

${ }^{\mathrm{z}} 1 \mathrm{~cm}=0.3937$ inch.

${ }^{\mathrm{y}}$ Means in the same column followed by the same letter are not significantly different using Fisher's protected least significant difference at $P<0.05$.

during the 3-year period following their establishment.

Although there were some variations in trunk diameter across treatment groups, the analysis of variance did not find enough evidence of a statistically significant effect of pruning on trunk diameter. The probability value of the Duncan test was greater than the threshold level of 0.05 .

NuMBER AND LENGTH OF SHOOTS. The analysis looked at the number of shoots added on average per plant and the average shoot growth across the three treatment groups at 1, 2, and 3 years after establishment, as well as the average growth per shoot. In the first 2 years, the unpruned trees had more shoots (Table 2). However, by year 3 the pruned trees had added more shoots than the control trees, leading to no difference in mean number of shoots at the end of the observation period (2010).

Average growth per shoot for the treated groups was significantly higher than for the control group. Trees that received $50 \%$ pruning at planting had an average limb growth $5.6 \mathrm{~cm}$ higher than the control trees. Those that were initially pruned at $75 \%$ had an average growth of $11 \mathrm{~cm}$ higher than the control group and $5 \mathrm{~cm}$ more than the $50 \%$ treatment group.

These findings were supported by previous work by Smith and Johnson (1981) who found that pecan trees that received either $25 \%$ or $50 \%$ top pruning maintain high shoot growth rates compared with trees that did not receive any pruning.

Shoup et al. (1980) found similar results for 5-year-old pecan trees. Essentially, their study suggested that $15 \%$ top pruning increases shoot growth over no pruning.
TOTAL SHOOT GROWTH. Although the total shoot growth (Table 3 ) was higher for the pruned trees, the differences were not statistically significant $(P>0.05)$. Wood (1996) found that pruned trees eventually grew more than unpruned trees so that there was no difference in total shoot length growth after 3 years. Note that although statistical significance was not found, Bayesian analysis with a prior distribution that implies pruning leads to more growth would yield a posterior distribution quite similar to the prior distribution. Thus, the results are consistent with the current practice of pruning trees at the time of transplanting.

\section{Conclusions}

Young pecan trees were subjected to three levels of pruning $(0 \%, 50 \%$, and $75 \%)$ to determine the effects of pruning intensity on trunk size and shoot growth. Pruning stimulated little or no effect on trunk diameter development. Pruning stimulates growth per shoot. Trees with no pruning initially had more shoots, but the average shoot length was less than for trees that received $50 \%$ or $75 \%$ of pruning. By year 3 , the number of shoots on all trees was similar, but the trees that had received pruning continued to have greater average shoot growth. The total length of all shoots was initially higher for the trees with no pruning, but the pruned trees had closed the gap by year 3 . Thus, the results show that the trees recovered well from severe pruning.

The Oklahoma Cooperative Extension Service (2019) recommends cutting off the top half of the tree when planting a bare-root tree. The results here are insufficient to argue that this recommendation needs to change. The results do suggest that for irrigated trees like those considered here, there is no need to worry about being too exact on how much of the tree is pruned, because it did not matter much whether $3 / 4$ of the top was removed or none at all.

\section{Literature cited}

Bahrun, A., C.R. Jensen, F. Asch, and V.O. Mogensen. 2002. Drought induced changes in xylem $\mathrm{pH}$, ionic composition, and ABA concentration act as early signals in field-grown maize (Zea mays L.). J. Expt. Bot. 53:251-263.

Brewer, P.B., H. Koltai, and C.A. Beveridge. 2013. Diverse roles of strigolactones in plant development. Mol. Plant 6:18-28.

Khan, U.Z., D.L. McNeil, and A. Samad. 1998. Root pruning of apple trees growth at ultra-high density affects carbohydrate reserves distribution in vegetative and reproductive growth. N. Z. J. Crop Hort. Sci. 26:291-297.

Kudo, T., T. Kiba, and H. Sakakibara. 2010. Metabolism and long-distance translocation of cytokinins. J. Integr. Plant Biol. 52:53-60.

Littell, R.C., G.A. Milliken, W.W. Stroup, and R.D. Wolfinger. 1996. SAS system for mixed models. SAS Inst., New York, NY.

McCraw, B.D. and M.W. Smith. 1998. Root pruning and soil type affect pecan root regeneration. HortTechnology 8:573-575.

Meadows, J.S. and J.R. Toliver. 1987. Three-year response of pecan to six methods of seedling establishment. South. J. Appl. For. 11:56-59.

Oklahoma Cooperative Extension Service. 2019. Starting pecan trees. Oklahoma State Univ. Ext. Fact Sheet 6207.

Puig, J., G. Pauluzzi, E. Guiderdoni, and P. Gantet. 2012. Regulation of shoot and root development through mutual signaling. Mol. Plant 5:974-983.

Shoup, S., R. Reavis, and C.E. Whitcomb. 1980. Effects of pruning and fertilizers on establishment of bare root deciduous trees. Oklahoma Agr. Exp. Sta. Res. Rep. P-803.

Smith, M.W. and J.L. Johnson. 1981. The effect of top pruning and root length on growth and survival of transplanted pecan trees. Pecan Qrtly. 15:20-22.

Su, Y., Y. Liu, and X. Zhang. 2011. Auxincytokinin interaction regulates meristem development. Mol. Plant 4:616-625.

Wells, N. 2017. Establishing a pecan orchard. Univ. Georgia Ext., Georgia Coop. Ext. Bul. 1314.

Wood, B.W. 1996. Establishing pecan transplants. HortTechnology 6:276-279. 